\title{
POSITION AND ROLE OF A WOMAN IN NATIONAL SOCIAL AND ECONOMIC DEVELOPMENT OF SERBIA
}

Since the beginning of the $20^{\text {th }}$ century it is a demographic fact that women represent over half of the population, while in public sphere they are marginalized. Even Hannah Arendt concluded that "in modern society women are the biggest minority" there is.

In the domain of rights (in subjective and objective sense of the notion) women of the 20th century have reached an equal status with men in principle, but in the 21st century between formal and actual right there is considerable discrepancy. Her right to work is obstructed, in political, economic or cultural level as well as in any given professional activity, regardles formally and legally ensured equality and basically accepted reality of the need for an enhanced participation of less represented gender on decision-making positions.

Printed media in Serbia makes clear they are marginalized, since they appear as expert collocutors almost nine times fewer than men (89.2: 10.8 percent in favor of men experts).

The effect of "glass ceiling" implies invisible yet efficacious obstacle in advancement to the highest organizational positions of women. Statistical data clearly shows that there are still no women in places of actual decision-making, and that they are less paid for the same work in comparison to men, her unequal position is evident from the insight to the company ownership structure, as well as remarkably lower representation on leading positions. Moreover, women have fewer possibilities of advancement in career, and get dismissed more often than men in the process of transition.

A woman is sometimes in an inequitable position when it comes to earning income for the exact same work carried out by a man, and she is actually not granted access to all positions and functions in the organization of a society. Therefore it is often a case of using "woman-alibi" in practice, that is directing certain women to high and influential public positions in order to prove there is no discrimination towards women by the society.

Nevertheless, without equal, better and more active participation of women, there shall be no faster or advantageous social and economic development.

Keywords: woman, glass ceiling, economic and social position, inequality

* Professor, Faculty of Culture and Media, John Naisbitt University, Serbia ntorlak@nezbit.edu.rs

** Bachelor In Business Administration, East Carolina University USA torlakpetar@gmail.com 


\section{Introduction}

It is a demographic fact in modern period of society's development that the number of women is in constant increase in relation to number of men, i.e. for a long time women makes more than half of population, while been marginalized in public sphere. Today, woman can be found in production, from factories to administration and managing position. She is not only irreplaceable support, but an active participant of all changes and movements in modern era. Since the beginning of 20 th century, until today, woman has significant active role on worlds, social, economical and political stage.

In the area of rights (both subjective and objective meaning of term) women has achieved, in principle, equal status with men. They were waiting for nearly two centuries that idea of equality become truly "human right". However, up to day, there are still discrepancies between formal and real rights. Woman's right to work is been obstructed, as in political, economical and cultural area, as well as in every other expert acting.

Hannah Arendt affirmed that "woman of modern society is also biggest minority" that exists. Even though mathematically demographic majority, woman in patriarchal society has minority status. French writer Simone de Beauvoir wrote how that authentic human being, by time become "woman" - a victim of tradition in dominant male culture.

As the woman through historical practice generally was excluded from politics, but also from production and all other important functions of society, both through ages theory was neither dealing with (nor giving significance) to the status of woman in given social-cultural and economical environment. Almost whole life of that invisible woman took place inside family, far away from public eyes and public importance, with strictly defined rules according to sex, anent gender (Djordjevic, 1975). In short terms, woman as "woman" is a product of social norms and rules which are male product.

Estimation of a woman as inferior being, formed based on biological and sexual delusions, is expressed not only in, for woman depreciative sayings and songs, but also in conceptions of philosophers, psychologists and statesmen. In that respect, famous misogynist Arthur Schopenhauer is cited, both with Immanuel Kant, Friedrich Nietzsche and Sigmund Freud. For example, Napoleon Bonaparte his opinion on woman, as an inferior being in relation to man, legalized for a whole century in "Code civile", greatest monument of bourgeois law and code of woman's imparity.

Therefore, Karl Marx set a thesis, which he took from Charles Fourier, claiming that "level of woman's emancipation is natural measure of general emancipation" (Marx, 1964)

Today, the position of woman is complex not only because of her economic, but also her demographic role. She is not only labour force, but she must give 
birth as well. She is simultaneously productive and reproductive power in society (Todorovic-Uzelac, 1987).

Feminists considered that appearance of modern organizations and bureaucratic carriers came as aftermath of specific gender configuration. They denote on two ways of gender implementation into structure of modern organizations. First, bureaucracies are distinguished by gender segregation on work place. When women became significant part of labour force, they were assigned to poor paid working positions on which they performed routine tasks. Chances for promotion were minimal. Second, bureaucratical career, by feminists, alluded male career, in which key part of a woman was giving support. At work place, women performed routine jobs, so men can focus on getting a promotion. In the sphere of family, women also supported career advancement of men - by taking care of house and raising children, so men can focus strictly on work. These two tendencies led to modern organizations become male reservation in which women were excluded from the government, without a chance to advance, and that, in addition, become victims of sexual harassment.

A research which had been performed in 21 countries (Davidson, Burke, 2004) showed that women on managing position are still grouped on lower management levels and in traditionally women's sectors of care, education and services, and not in those with highest incomes, like energy, information technologies (IT) and transport industry. They are still underpaid to male colleagues on all levels of hierarchy ladder, including board of directors and are hardly make breach through "glass ceiling" which stops them from reaching top management functions and positions. That is also the case in the USA where women take $45 \%$ of managing positions, but make only $5 \%$ of top management - the percentage with small variations during last quarter of 20th and first decade of 21st century.

Publication of book "Breaking the Glass Ceiling" (Morrison, White, Van Velsor, 1987) in USA, gave new swing to research of women in management. Women gain level of knowledge and experience requested by those positions, paying bigger price than men, but are still facing with infamous "glass ceiling" (Powell, 1999). So, whilst women, on global level, represent nearly half of labour force, they still represent weak percentage in high managers structure (Wirth, 2001).

In leadership domain, man remains what he used to be during the evolution of mankind - a hunter, not only because he brings more food, but contracts.

\section{Attitude toward woman and her role in Serbian transitional society}

During the past millennium, women were subordinated to male domination, witnessed by some theoretical sources, while affirmative documents about women as driving force of society are very rare. So, based on myths, customs and current regulations, it can be concluded that misogyny enjoys long and well established, strong tradition (Kandido-Jaksic, 2001). 
Escalation of misogyny (organized, institutionalized hostility or hate toward women) comes also during the transition process. Phenomenon of misogyny spread is one more symptom of Serbian society's "sickness" and culture of 90's. Crisis of man's roles and identities is characteristic for other societies in transition and, on the other side, experience of wars which increased creation of "men communities" and evocation of "warrior's memory", with ritual exclusion of women, or their inclusion under conditions that brings them down to "servants of warriors", created an impulse in Serbia which was, to a certain degree, situational conditioned, but it's clear that misogyny itself, as occurrence, is not by no means something instantaneous or transient, but with (too)long history.

Wars which were led during the 90's in former Yugoslavia, UN sanctions, followed by privatization process and transition, brought back women into privacy sphere and distanced them from politics and public life (Torlak, 2011).

Position of women in our society suggests their marginalization, while stereotype pictures of gender relationships supports traditional, polarized gender roles, according to which women are passive, inferior, incompetent to represent official discourse or to offer expert knowledge in the matter of public interest, whilst their achievements are been ignored. Statistic data clearly indicates that women are still not to be found where the decisions are really made, and for the same job they are less paid, have less opportunities to advance, whilst lose their job more often than men during transition process. All this is confirmed in publication by Statistical Office of the Republic of Serbia (SORS) called "Women and men in Republic of Serbia" published in 2014: the women makes 51,3\% of total population of Serbia, but are underpaid than men, they work more on wageless jobs than men, they are excluded from decision making processes and are more subjective to poverty. Besides: women are most common in the category "supported person" (57,6\%) followed by women whose main income is their pension (57,0\%), scholarship (56,5\%) and other social incomes (55,5\%).

\subsection{Unemployment structure}

In research by Foundation for the Advancement of Economics (FREN) which was published in 2013, course of employment in Serbia in period 2005 - 2010 has been analyzed, followed by course of unemployment rate by gender and age.

In mentioned research, the rate of an employment has been considered (15- 64 years of age) according to gender and age in five years period and the conclusions are as follows: the rate of employment of women in April 2010 was 40,2\% and is far less than the rate of employment of men $(54,3 \%)$ although this difference is reduced in period 2005 - 2010. Furthermore, the rate of employment of women in Serbia is lower when compared with $27 \mathrm{EU}$ countries (58,6\% in 2009), but also from the rate of employment of women in surrounding countries (Croatia, Bulgaria, Romania). 
Rate of unemployment in April 2013 in Serbia grew by 1,7\% in regard to October 2012 and is at $24,1 \%$ at total, or $22,3 \%$ for male and $26,5 \%$ for female population (Labour Force Survey, 2013).

Gender imparities are considerably expressed in numerous aspects. They are manifested through insufficient political participation of women, economical imparities, and unequal distribution of commitments in family, unbalanced rate of power in privacy sphere etc. Only 5\% of women are presidents of municipalities/ majors, and $29 \%$ of women are municipal or city alderman. Women are rarely on position of manager of a household: $15,9 \%$ of women and $84,1 \%$ of men (BlagojevicHewson 2011, Babovic 2010).

\subsubsection{Gender gap in ownership over companies}

According to the data from Serbian Business Registrations Agency, in August 2014 active companies had 217.290 proprietary shares. From that number, only $26,8 \%$ (58.205) were owned by women, while the rest of $73,2 \%$ were owned by men. Related to research period on entrepreneurship of women from 2011, when women had $25,2 \%$ of proprietary shares, these data are showing on extremely small move toward closing of gender gap in ownership over companies.

\subsubsection{Gender gap on positions of company management}

In order to get a correct insight on gender gap in the matter of company management, it is necessary to focus our attention on the highest managing positions, i.e. positions holding most power in company. Those are usually positions of general manager, and in case of limited companies (Ltd) positions of member in Board of directors. According to data from Serbian Business Registrations Agency from 2014, women were holding 25,8\% of highest managing positions, which represents slight increase of share from $22 \%$ in 2011.

These findings once again support the fact that women are hard to "breach" to leader position when competition with men is higher, i.e. when there are more candidates for those positions. These findings are in order with previous ones which were showing existence of, so called, "glass ceiling" in vertical mobility of women to highest managing positions in the companies (Babovic, 2007, 2010, 2012). Differences in ownership of proprietary shares of women and men were not noticed to a significant extent between regions nor economy sectors. Smaller changes are registered only in some "typically woman's" sectors like administrative support and services, health care and social protection and sector of classic services, in which women owns between $30 \%$ and $40 \%$ of proprietary shares, whilst in other branches this percentage is between 15 and 30\% (Babovic, 2012).

Data from 2011 on regional differences, in the matter of persons performing management functions or holding positions in Board of directors in companies, 
shows that women outside Belgrade region are rarer among directors and significantly rare among members in Board of directors, than in case of companies from Belgrade (Babovic, 2012).

\subsubsection{Public agencies}

Public agencies are organizations whose founder is the Government and which are founded for purpose of development, expert and regulatory tasks of public interest, and in Serbia there are 170 different agencies.

Observing the composition of management bodies in eight selected agencies, which has been selected based on influence they have on social relationships in economy and society in general and their significance on economical and financial flows in the country (Agency for privatization, Serbian Business Registrations Agency, Agency for Development of Small and Medium-sized enterprises of Republic of Serbia, Anti-corruption Agency of Republic of Serbia, Serbia Investment and Export Promotion Agency, Agency for Energetic Efficiency, Regulatory Authority of Electronic Media, Regulatory Agency for Electronic Communications and Postal Services), we can see that they have only one woman on position of director, and same situation is with deputy and other higher positions in these institutions.

\subsubsection{Public enterprises}

When discussing of public enterprises, Serbia follows bad trend present in other parts of the world, and that is women are represented with only $10 \%$ on managing positions in public enterprises.

When discussing the topic about women on high managing positions inside European Union, more and more is contemplating the idea of introduction of quota system in order to increase the number of women in public enterprises' Boards of director up to $40 \%$ by the year 2020 (ec.europa.eu/commision2014).

There is not systematic solution for this problem, not even in Serbia. According to data from National Strategy for Improving the Status of Women and Promotion of Gender equality (2009 - 2015), women in Serbia participate with 30,5\% on managing positions in society and economy, out of which only $20,8 \%$ as directors and as Head of Board of directors only with 14,3\% ("Official Gazette of Republic of Serbia")

\section{3.“Glass ceiling” - invisible, but strong barrier}

The "glass ceiling" effect points to invisible but strong barrier to advancement on highest organizational positions of women (and minorities). This term came into use in feministic economy with an aim to mark gender discrimination in vertical mobility inside organizations, and later widen to other forms of 
discrimination. According to Rosabeth Moss Kanter, the solution is above all in providing numerical strength. When the percentage of women inside an organization reaches $35 \%$, they become minority group. Then they can form coalitions which can change ratio and culture inside an organization (corporation). Group becomes really balanced on $40 \%$, even better on 50\% (R. Moss Kanter, 1977).

By analyzing data, I came to the conclusion that a situation is somewhat better in cultural activities rather than in economy. As for the city institutions, women are usually heads of libraries, schools, kindergartens, museums and centres for social work. For example, out of 19 theatres in Belgrade, only six of them have woman as a director, and out of 35 directors of Belgrade's museums and commemorative collections, nine are woman (Torlak, 2011).

When discussing those employed in education, women are mostly teachers in primary schools, where they make $71,8 \%$ of total employees - almost as men on faculties $-70,6 \%$. Since the foundation of Serbian Academy of Sciences and Arts back in 1887 , no woman has ever been a president.

\section{Politics as creator of social-economical relationships}

It's a common saying that prostitution is an oldest trade, as women trade. But much older and longer lasting trade, as a men trade, is politics. It simultaneously conditionate and kept state in which the woman is, and it (politics) became as limitation as well as mean in struggle for liberation from that condition and for general emancipation of woman (Papic and Sklevicki, 2003).

In former Yugoslavia, back in the 80 's, $17 \%$ of women were chosen into parliaments, and in period from 1989, after wars and changes, the share of women in political life of whole region plunged dramatically, so women became invisible in public and political sphere of management and decision making - in Serbia only $1,6 \%$. After the elections in 2000, the National Assembly of Serbia and Montenegro had only 10 women, out of 178 deputies.

Although Electoral Law of Serbia from 2004 introduced quota system which alluded that at least $30 \%$ of women must be on political parties' candidates list the woman on leader position of political party is almost not to be found.

Let's say, from 1839 until 2011, only two women were Belgrade's mayor: Dr Slobodanka Gruden (1993 - 1994) and Radmila Hrustanovic (2001 - 2004).

There are almost no women when it comes to decision making, except where the politics is been operationalized. So, they take part in the implementation, but not in the making of decisions. It is significant to emphasize that currently heads of National Assembly of Republic of Serbia and National Bank of Serbia are women, but this research showed that even in the highest bodies of the National Assembly, where all the decisions are been made, and those are Assembly boards and chiefs of Parliamentary groups, is conspicuously smaller presence of women 
on managing positions. Most obvious discrepancy is noticeable in the matter of chairman of the Assembly boards, where we have 26 presidents and only three female presidents. The same situation is with leaders of Parliamentary clubs, where the ratio is 9:1 in favour of men (Torlak, 2011).

\section{Media as mirror of the reality}

The competence of women is most commonly invisible; neither their needs nor their achievements are noticed. Judging by the newspapers, women are not asked for any relevant issue in the society (Milivojevic, 2004).

According to the research carried out during 2006 by the Media centre from Sarajevo, Bosnia and Herzegovina, women in printed media from Serbia, Croatia and Bosnia and Herzegovina are present five times less than men.

By following three national daily newspapers in all three countries (in case of Serbia those were "Blic", "Politika" and "Vecernje novosti") it has been concluded that as interlocutor - women's experts are present nearly nine times less than men (89,2:10,8 percent in favour of men experts).

Also, the media devotes very small percentage of news to women. That percentage never goes over 15\%, except in period of elections or celebration of International Women's Day, March 8th.

Most present women in the media are the celebrity ones. Women are mostly visible in culture, local crime and entertainment columns. In local crime column, usually because been a victim of violence, and almost none in politics, economy, health care or education columns.

If we look more concretely, the journalism is slowly becoming female profession (Jevtovic, 2007). Once, the number of women in this field was negligible, while today their dominancy is visible with a naked eye.

Because of that, current disbalance is indefensible (mainly in managing structures and in managing sphere of journalism itself in favour of men) due to its deep roots in more primitive heads, at those who found themselves at influential positions, but with lower education level than women.

In local media, misogyny has increased simultaneously with privatization of media and with introduction of political pluralism, which often alluded ruthless struggle on political market, with women under attack by hatred speech in order to eliminate political opponent.

Holders of misogynous messages in the local mass-media are not only men. With a feminization of journalistic profession in Serbia, women (a large number of journalists and editors) become accomplices in misogynous acting. In the women themselves often doesn't exist a reflex necessary to recognize misogyny: the woman journalists in media with high number of copies (mostly in tabloids), as well as journalists and hosts of popular TV shows in Serbia create an image 
of a woman as she is expected to be in the primitive patriarchal environment, or they are been reconciled with certain facts about the place and the acceptance of a woman in society (misogyny as a part of culture in which we live), but there isn't much protest among women due to the expansion of misogyny.

\section{Conclusion}

The fact is that women are still noticeable minority in political, economical, social and media life in Serbia, no matter to formally and legally secured equality and generally accepted reality for need to increase participation of less present gender on decision making positions (Mitrovic, 2012).

Due to all above mentioned, the role of a state in improvement of women's position in all spheres or living is primary and unchangeable, but big responsibility lies on all members of the society, as well as on public information bodies, because it is obvious that collective prejudices and attitudes must be changed.

Changes in the world, and especially in our neighbourhood, unavoidably reflects to our country which is going through transition and transformation phase. Slowly, and depending on validity of priorities, specific situations and social circumstances, it is certain that an attitude about woman must be changed, first as equal sex and gender in every society, including our own. So far, we are witnesses of an asymmetrical power which - in the society dominated by male point of view - comes from differences between genders interpreted on woman's disadvantage. Gender imparity is without a doubt a systematic question and it needs to be solved as key barrier to development and comprisable growth (Oxfam, 2014).

From a woman's point of view, all of this is being supported by adopted inferiority, "good manners", education and everything that influence on apperception that these subjects (gender equality) are not to be talked about "because there are more important subjects", and that when everybody else gets better, so shall be to the women.

This is why the woman is in unequal position regarding incomes for the same work as a man, without real access to all positions and functions in organization of the society. There are still work positions that are "by default" reserved for men. This is why often in practice there is use of "woman alibi", i.e. on high and influential public positions and functions (but not all), some women are been appointed just to show that there is no discrimination by the society towards women.

Frontal confrontation between men's and women's qualities is worthless and harmful. There are qualities of male and female type, but that doesn't mean that we necessarily find first ones at men, and the second ones at women. Female management does not exists, management on women's way - does. Widely 
observed, implementation of non-discriminative selection for leader positions would lead to greater equity and economical rationality, the characteristics which favour long-term success of organizations. Also, there are results of researches which unmistakably show that the countries in which smaller presence of women on labour market in relation to their number in population, are economically under-developed.

A study published by World Bank gives us arguments that gender equality, which allude accumulation of education, health care and property and usage of these contributions with an aim of exploitation of economical possibilities and generating an income, can improve economical efficiency and results in three main ways. First, by removing barriers which restrain women to have same access to education, economical possibilities and productive incomes as men, resulting in wider gains in productivity. Second, reclamation of women's status accelerates many other development results, including ones on behalf of their children. And third, all of this will most likely lead to more representative and inclusive institutions and political choices and therefore to better developing course of one country (Gender Equality and Development, 2012).

So it doesn't hurt to say again that economical empowerment of a women, including their stronger participation in labour force, is key for economical growth. 


\section{Literature}

- Anketa o radnoj snazi, oktobar 2012. godine, april 2013. godine; Republički zavod za statistiku

- Babović, M. (2012) Polazna studija o preduzetništvu žena u Srbiji, UN Women, Beograd.

- Blagojević Hjuson, M. (2011): Žene i muškarci u Srbiji: šta nam govore brojke?, Program Ujedinjenih nacija za razvoj, Beograd

- Branimir Mitrović, Rodna nejednakost na pozicijama odlučivanja u Srbiji Republika Srbija, ministarstvo rada, zapošljavanja i socijalne politike, Uprava za rodnu ravnopravnost, 2012.

- Davidson, M.J. and R.J. Burke (2004), Women in Management Worldwide: Facts,Figures and Analysis, Farnham; UK: Ashgate, Publishing.

- Đorđević, J. (1975), Žensko pitanje, Beograd: Radnička štampa

- Jevtović, Z. (2007) Slika žena u ramu demokratije, Politička revija, Godina (XIX) VI, vol=14, Бр 2-4/2007. Beograd, стр 727-729.

- Kanter R, 1977, "Men and Women of the corporation", New York: Basic Books

- Katunarić, V. (1984), Ženski eros i civilizacija smrti, Zagreb.

- Katuranić, V. (1987) „Autoritarnost-etnocentrizam-seksizam i društvene grupe“, Sociologija, 4, 603-610.

- Marks, K. (1964), Kapital, Beograd: Kultura

- Milivojević, S. (2004) Žene i mediji - strategija isključivanja. Genero, (posebno izdanje). Beograd str. 15-29

- Moranjak-Bamburać, N. Jusić, T.. Isanović, A (2006) Stereotyping: Representation of Women in Print Media in South East Europe, Sarajevo: Mediacentar

- Morrison, Ann M. , R. P. White, E. Van Velsor, and the Center for Creative Leadership. 1987. Breaking the glass ceiling. New York: Addison-Wesley.

- Nacionalne strategije za poboljšanje položaja žena i unapređivanje ravnopravnosti polova (2009-2015) Управа за родну равноправност Министарства рада и социјалне политике Републике Србије

- Papić, Ž., Sklevicki, L., ur. (2003) Antropologija žene. Beograd: Biblioteka XX vek

- Powell, R. (1999), In the Shadow of Power, Publisher: Princeton University Press.

- Službeni glasnik RS (27.02.2009) br. 015, Beograd

- Todorović, N. (1987) Ženska štampa i kultura ženstvenosti, Naučna knjiga, Beograd.

- Torlak, N. (2011) Прећуткивање, опструкција, маргинализација: препреке на путу женског експертског деловања, Kultura 131,стр.243-254, Београд

- Wirth, L., (2001). Breaking through the glass ceiling: Women in management. Geneva: International Labour Office. 
- Žene i muškarci u Republici Srbiji, Republika Srbija Republički zavod za statistiku, Prvo izdanje, Beograd, 2014.

- Бабовић М. (2012) Полазна студија о предузетништву жена у Србији, UN. Women, Београд.

\section{Web:}

- http://ec.europa.eu/commission_2010-2014/reding/womenpledge/index_ en.htm

- http://www.fren.org.rs/sites/default/files/Procena_uticaja_politika_u_oblasti_zapošljavanja.pdf

- World Bank (2012). Gender Equality and Development. World Development Companion Report. http://siteresources.worldbank.org

- Oxfam. (2014). The G20 and Gender Inequality: How the G20 can advance women's rights in employment, social protection, and fiscal policies." Briefing Paper. http://www.oxfam.org.

- http://www.fren.org.rs/sites/default/files/Procena_uticaja_politika_u_oblasti_zapošljavanja.pdf

- http://www.sindikat.rs/ekonomija_files/statistika/Osnovni\%20 podaci_1_2013.pdf

- biblioteka narodne skupštine Datum: 18.11.2013. Br. Z-18 /13

- http://www.apr.gov.rs 


\section{Prof. dr Nada Torlak}

Fakultet za kulturu i medije, Univerzitet Džon Nezbit, Beograd

Petar Torlak

Bachelor In Business Administration, East Carolina University, USA

\section{POLOŽAJ I ULOGA ŽENE U NACIONALNOM DRUŠTVENOM I EKONOMSKOM RAZVOJU SRBIJE}

Od početka 20. veka demografska je činjenica da žene predstavljaju više od polovine stanovništva, dok su u javnoj sferi marginalizovane. I Hana Arendt je utvrdila da je "žena modernog društva najveća manjina" koja postoji.

U oblasti prava (u subjektivnom i objektivnom značenju tog pojma) žene su u 20. veku postigle u načelu ravnopravan status sa muškarcima, ali $i$ u 21. veku formalno $i$ stvarno pravo su u raskoraku. Njeno pravo na rad se opstruira, kako na političkom, ekonomskom ili kulturnom planu tako i na svakolikom drugom ekspertskom delovanju, bez obzira na formalno-pravno obezbeđenu ravnopravnost $i$ načelno prihvaćenu realnost potrebe o povećanju učešća manje zastupljenog pola na pozicijama odlučivanja.

Da su marginalizovane jasno je i uvidom u štampane medije u Srbiji, gde se kao sagovornici-eksperti pojavljuju skoro devet puta manje od muškaraca (89,2: 10,8 odsto u korist eksperata muškaraca).

Efekat „staklenog plafona“ ukazuje na nevidliivu ali snažnu prepreku napredovanja na najviše organizacione položaje žena. Statistički podaci jasno pokazuju da žena još uvek nema tamo gde se stvarno odlučuje, a za isti posao su manje plaćene nego muškarci, o njenom neravnopravnom položaju govore i uvidi u strukturu vlasništva preduzeća, kao i upadljivo manja zastupljenost na rukovodećim pozicijama. Osim toga, žene imaju manje mogućnosti za napredovanje u službi, a u procesu tranzicije češće nego muškarci ostaju bez posla.

Žena je nekad u neravnopravnom položaju u pogledu sticanja dohotka za isti rad kao i muškarac, i njoj stvarno nisu dostupna sva mesta $i$ funkcije u organizaciji društva. Zato se često primenjuje praksa upotrebe "žene-alibija", tj. na visoke i uticajne javne položaje i funkcije upućuju se pojedine žene da bi se time pokazalo da u odnosu društva prema ženi nema diskriminacije.

Ipak, bez ravnopravnog, boljeg i aktivnijeg učešća žena, nema ni bržeg ni kvalitetnijeg socijalnog i ekonomskog razvoja.

Ključne reči: žena, stakleni plafon, ekonomski i društveni položaj, neravnopravnost 